\title{
PENGARUH PENDIDIKAN KESEHATAN DENGAN AUDIO VISUAL TERHADAP PENGETAHUAN DAN MOTIVASI IBU MENYUSUI SECARA EKSKLUSIF DI PUSKESMAS GAMBIRSARI SURAKARTA
}

\author{
Eni Rumiyati ${ }^{1}$, Erinda Nur Pratiwi ${ }^{2}$, Siti Nurjanah ${ }^{3}$ \\ ${ }^{1,2,3}$ Fakultas Ilmu Kesehatan Universitas Kusuma Husada Surakarta \\ enirumiyati@ukh.ac.id
}

\begin{abstract}
ABSTRAK
ASI ekslusif merupakan kebutuhan dasar bagi seorang bayi baru lahir yang paling mendasar. Pemberian ASI merupakan wujud kasih sayang dari seorang ibu yang berpengaruh terhadap kualitas hidup bayi dimasa mendatang. Pemberian ASI eksklusif di Indonesia cenderung rendah, pada 2016 sedikit mengalami peningkatan sebesar 54,0\%. Cakupan pemberian ASI Eksklusif di Kota Surakarta tahun 2014 sebesar 67,7\%. Di Kota Surakarta, ratarata cakupan pemberian ASI eksklusif pada tahun 2013 sebesar 55,7\%. Angka cakupan pemberian ASI eksklusif terendah salah satunya adalah Puskesmas Gambirsari 41,7\%. Media mempunyai peranan yang sangat penting dalam menentukan keberhasilan proses penyampaian pesan. Media yang digunakan adalah bisa dengan menggunakan Audio visual berupa video tentang ASI Eksklusif. Penelitian ini bertujuan untuk mengetahui penyuluhan ASI eksklusif dengan Audio visual terhadap pengetahuan dan motivasi untuk menyusui secara eksklusif di Puskesmas Gambirsari, Surakarta. Metode penelitian yang digunakan adalah pra-eskperimen (pre-experiment design) penelitian ini menggunakan rancangan One Group Pretest-Postest. Analisis data dengan uji paired simple t-test. Populasi dalam penelitian ini adalah 30 orang. Seluruh polulasi diunakan sebagai sampel penelitian (total sampling). Penelitian ini menggunakan analisis data dengan uji paired simple t-test dengan nilai signifikansi $p$-value sebesar 0,000 dengan taraf signifikansi $\mathrm{p}<0,05$. Hal ini dapat disimpulkan bahwa ada pengaruh pendidikan kesehatan ASI Eksklusif dengan audio visual terhadap pengetahuan dan motivasi ibu menyusui secara eksklusif di Puskesmas Gambirsari Surakarta.
\end{abstract}

Kata kunci : Pendidikan Kesehatan, ASI Eksklusif, Audio Visual, Pengetahuan, Motivasi

\begin{abstract}
Exclusive breastfeeding is the basic requirement for the most basic newborns. Breastfeeding is a form of love from a mother that affects the quality of life of the baby in the future. Exclusive breastfeeding in Indonesia tends to be low, in 2016 slightly increased by $54.0 \%$. Coverage of exclusive breastfeeding in Surakarta in 2014 was 67.7\%. In Surakarta City, the average coverage of exclusive breastfeeding in 2013 was 55.7\%. The lowest coverage rate for exclusive breastfeeding is Gambirsari Public Health Center 41.7\%. The media has a very important role in determining the success of the message sending process. The media used are able to use audio visual video in the form of exclusive breastfeeding. This study aims to determine counseling for exclusive breastfeeding with audio-visual knowledge and motivation for exclusive breastfeeding in Gambirsari Public Health Center, Surakarta. The research method used was a pre-experimental design (pre-experimental design) of this study using One Group Pretest-Posttest design. Data analysis using simple paired t-test. The population in this study was 30 people. All polls are used as research samples (total sampling). This study uses data analysis with a simple paired t-test with a p-value of 0,000 significance $p<0.05$. It can be concluded that there is an influence of exclusive breastfeeding health education with audio visual on the knowledge and motivation of breastfeeding mothers exclusively at Gambirsari Public Health Center Surakarta.
\end{abstract}

Keywords : Health Education, Exclusive ASI, Audio Visual, Knowledge, Motivation 


\section{PENDAHULUAN}

Indikator keberhasilan pembangunan adalah mampu mencapai kesejahteraan hidup bagi setiap individu maupun masyarakat secara luas. Keberhasilan dari pembangunan kesehatan untuk mencapai sasaran dan target yang strategis ditentukan oleh keberhasilan dalam menciptakan dan melestarikan perilaku hidup sehat dari masyarakat. Program peningkatan pemberian Air Susu Ibu (ASI) kepada bayi khususnya ASI eksklusif merupakan program prioritas pemerintah dalam mencapai kesejahteraan dan meningkatkan perilaku hidup sehat bagi masyarakat. ASI merupakan makanan yang terbaik dan sempurna bagi bayi karena ASI mengandung semua zat gizi yang dibutuhkan untuk perkembangan dan pertumbuhan seorang bayi (Depkes, 2010).

ASI ekslusif adalah merupakan kebutuhan dasar bagi bayi baru lahir yang paling mendasar untuk tercukupinya ASI. Pemberian ASI merupakan wujud kasih sayang dari seorang ibu yang berpengaruh terhadap kualitas hidup bagi bayi dimasa mendatang (IDAI, 2008). Air s Susu Ibu (ASI) eksklusif berdasarkan Peraturan Pemerintah Nomor 33 Tahun 2012 adalah ASI yang diberikan kepada bayi sejak dilahirkan selama enam bulan, tanpa menambahkan dan atau mengganti dengan makanan atau minuman lain (kecuali obat, vitamin, dan mineral).

ASI adalah cairan putih yang dihasilkan oleh kelenjar payudara ibu melalui proses menyusui (Khasanah, 2011). ASI merupakan makanan yang dipersiapkan untuk bayi dimulai dari kehamilan payudara seorang ibu hamil sudah mengalami perubahan untuk dapat memproduksi ASI. ASI memiliki kandungan gizi yang tinggi dibandingkan jenis makanan buatan manusia ataupun susu yang berasal dari hewan seperti sapi, kambing maupun kerbau.

Menyusui memiliki manfaat sangat baik bagi ibu maupun bayi. Manfaat bagi ibu yaitu membantu mengeluarkan oksitosin yang dapat mencegah perdarahan, mempercepat involusi uterus, dan merasa dibutuhkan oleh anaknya. Manfaat ASI bagi bayi yaitu sebagai antibodi, meningkatkan kecerdasan bayi dan pertumbuhan bayi menjadi baik (Sunardi, 2008).

Pemberian ASI eksklusif di Indonesia cenderung masih rendah, pada tahun 2012 sebanyak $48,6 \%$, tahun 2016 sedikit mengalami peningkatan sebesar 54,0\%. Mengacu pada target tahun 2016 yang sebesar 42\%, maka secara nasional cakupan pemberian ASI eksklusif pada bayi usia kurang dari enam bulan sebesar 54,0\% telah mencapai target (Kemenkes, 2013).

Cakupan pemberian ASI Eksklusif di Kota Surakarta tahun 2014 sebesar 67,7\%. Di Kota Surakarta, rata-rata cakupan pemberian ASI eksklusif pada tahun 2013 sebesar 55,7\%. Angka cakupan pemberian ASI eksklusif tertinggi terdapat di wilayah kerja Puskesmas Gajahan $80 \%$ dan cakupan terendah terdapat di 5 wilayah kerja Puskesmas kota Surakarta yaitu salah satunya Puskesmas Gambirsari 41,7\% (Dinkes Surakarta 2015).

Media mempunyai peranan yang sangat penting dalam menentukan keberhasilan dalam proses penyampaian pesan. Pemilihan media yang tepat akan sangat membantu keberhasilan proses penyampaian pesan kepada audien, sebaliknya penggunaan media yang tidak tepat akan mempersulit audien dalam memahami pesan yang disampaikan. Jenis media yang dapat digunakan antara lain adalah media cetak, media elektronik dan media papan. Media cetak seperti booklet, leaflet, buku, flyer, flip chart dan poster. Media elektronik seperti televisi, radio dan video serta media papan(Notoatmodjo, 2014). Pendidikan kesehatan tentang ASI eksklusif dapat diberikan melalui media salah satunya adalah media video.

\section{METODE}

Jenis penelitian yang digunakan dalam penelitian ini adalah rancangan pra-eskperimen (pre-experiment design) dengan rancangan "One Group Pretest-Postest" dalam rancangan ini tidak ada kelompok pembanding (kontrol), tetapi sebelumnya sudah dilakukan observasi pertama (pretest) yang memungkinkan peneliti dapat menguji perubahan-perubahan yang terjadi setelah adanya eksperimen (Notoadmodjo, 2010). Bentuk penelitian ini menggunakan rancangan One Group Pretest-Postest. Penelitian ini dilakukan dengan sasaran adalah ibu hamil trimester 3 yang berkunjung ke Puskesmas Gambirsari Surakarta. Besar populasi penelitian ini adalah 30 orang. Seluruh populasi diambil sebagai sampel penelitian (total sampling).

Variabel bebas pada penelitian ini adalah penyuluhan ASI eksklusif dengan audio visual dan variabel terikatnya adalah pengetahuan dan motivasi ibu dalam memberikan ASI Eksklusif. Populasi dalam penelitian ini adalah 30 orang. Seluruh polulasi digunakan sebagai sampel penelitian (total sampling). Penelitian ini menggunakan analisis data dengan uji paired simple t-test. 


\section{HASIL}

\section{Karakter Responden}

Tabel 1. Karakteritik responden

\begin{tabular}{|c|c|c|c|}
\hline \multirow{4}{*}{$\begin{array}{l}\text { No } \\
1\end{array}$} & Variabel & Jumlah & Prosentase \\
\hline & Umur & & \\
\hline & a. 20-30 tahun & 26 & 86 \\
\hline & b. $31-40$ tahun & 4 & 14 \\
\hline \multirow[t]{3}{*}{2} & Gravida & & \\
\hline & a. Primigravida & 7 & 23 \\
\hline & b. Multigravida & 23 & 77 \\
\hline \multirow[t]{5}{*}{3} & Pendidikan & & \\
\hline & a. $\mathrm{SD}$ & 2 & 6 \\
\hline & b. SMP & 8 & 27 \\
\hline & c. SMA & 17 & 57 \\
\hline & d. PT & 3 & 10 \\
\hline \multirow[t]{4}{*}{4} & Pekerjaan & & \\
\hline & a. PNS & 2 & 6 \\
\hline & b. IRT & 17 & 57 \\
\hline & c. Swasta & 11 & 37 \\
\hline \multicolumn{2}{|c|}{ Total } & 30 & 100 \\
\hline \multicolumn{2}{|c|}{$\begin{array}{l}\text { Berdasarkan pada tabel } 1 \text { tersebut } \\
\text { menunjukkan bahwa responden dalam } \\
\text { penelitian paling banyak masuk pada usia } 20- \\
30 \text { tahun sebanyak } 26 \text { orang }(86 \%) \text {, usia } 31-40 \\
\text { tahun sebanyak } 4 \text { orang }(14 \%) \text {. Responden } \\
\text { terbanyak adalah multigravida atau telah } \\
\text { memiliki lebih dari satu anak sebanyak } 23 \\
\text { orang }(77 \%) \text {, primigravida atau baru pertama }\end{array}$} & $\begin{array}{l}\text { ter } \\
(57 \\
\text { Pe } \\
\text { ora } \\
\text { seb } \\
\text { ora } \\
\text { seb } \\
\text { kri }\end{array}$ & $\begin{array}{l}\text { sebanyak } 17 \text { orang } \\
\text { ak } 8 \text { orang }(27 \%) \text {, } \\
\text { ang }(10 \%) \text { dan SD } 2 \\
\text { an terbanyak adalah } \\
\text { gga (IRT) sebanyak } 17 \\
\text { orang (37\%) dan PNS } \\
\text { Umur reponden dalam } \\
\text { si aman untuk hamil. }\end{array}$ \\
\hline
\end{tabular}

\section{Pengetahuan Responden Tentang ASI Eksklusif}

Tabel 2. Pengetahuan responden tentang ASI Eksklusif

\begin{tabular}{|c|c|c|}
\hline \multicolumn{3}{|c|}{ Pre Post } \\
\hline 1 & Baik & $5(17 \%)$ \\
\hline 2 & Cukup & $15(50 \%)$ \\
\hline 3 & Kurang & $10(33 \%)$ \\
\hline $\begin{array}{l}\text { menu } \\
\text { pada } \\
15 \text { o } \\
(33 \% \\
\text { Penge } \\
\text { terban }\end{array}$ & $\begin{array}{l}\text { Berdasarkan tabel } 2 \text { tersebut } \\
\text { njukkan bahwa pengetahuan responden } \\
\text { saat pre test berada pada kriteria cukup } \\
\text { rang }(50 \%) \text {, kriteria kurang } 10 \text { orang } \\
\text { dan baik sebanyak } 5 \text { orang }(17 \%) \text {. } \\
\text { atahuan responden pada saat post test } \\
\text { hyak pada kriteria baik } 26 \text { orang }(86 \%) \text {, }\end{array}$ & $\begin{array}{l}\text { kriteria cukup sebanyak } 4 \text { orang (13\%) dan } \\
\text { pada kriteria Kurang tidak ada. Pada } \\
\text { pengetahuan responden tentang ASI Eksklusif } \\
\text { terdapat peningkatan pengetahuan ibu setelah } \\
\text { diberikan pendidikan ASI Eksklusif dengan } \\
\text { menggunakan audio visual tentang ASI } \\
\text { Eksklusif. }\end{array}$ \\
\hline
\end{tabular}


Sekolah Tinggi Ilmu Kesehatan Bakti Utama Pati

\section{Motivasi responden untuk menyusui secara Eksklusif}

Tabel 3. Motivasi responden untuk menyusui secara Eksklusif

\begin{tabular}{cccc}
\hline No & Motivasi & Pre & Post \\
\hline 1 & Tinggi & $11(36 \%)$ & $22(73 \%)$ \\
\hline 2 & Sedang & $17(57 \%)$ & $8(27 \%)$ \\
\hline 3 & Kurang & $2(7 \%)$ & $0(0 \%)$ \\
\hline
\end{tabular}

Pada tabel 3 menunjukkan bahwa

motivasi ibu hamil untuk menyusui secara

eksklusif sebelum penyuluhan masuk pada

kriteria sedang sebanyak 17 orang (57\%)

setelah dilakukan penyuluhan dengan video terdapat perubahan kriteria menjadi motivasi tinggi dalam menyusui eksklusif sebanyak 22 orang $(73 \%)$.

\section{Analisis Data Uji Paired Simpel t-test}

Tabel 4. Pengaruh penyuluhan ASI Eksklusif dengan Audio Visual terhadap pengetahuan dan motivasi ibu hamil untuk menyusui secara eksklusif.

\begin{tabular}{llcccc}
\hline & Variabel & Mean & SD & $T$ & $p$-value \\
\hline Pengetahuan & Pretest- Postest & -3.600 & 1.793 & -10.999 & 0.000 \\
Motivasi & Pretest- Postest & -2.233 & 1.547 & -7.909 & 0.000 \\
\hline
\end{tabular}

Berdasarkan tabel 5.5 diatas menunjukkan bahwa ada pengaruh penyuluhan ASI Eksklusif dengan Audio Visual terhadap pengetahuan dan motivasi ibu hamil untuk menyusui secara eksklusif. Terbukti dengan nilai signifikansi $p$-value sebesar 0,000 karena $\mathrm{p}<0,05$ maka hipotesis diterima.

\section{PEMBAHASAN}

\section{Karakteristik Responden}

Penelitian ini dilakukan kepada 30 responden. Responden dalam penelitian ini paling banyak masuk pada usia 20-30 tahun sebanyak 26 orang (86\%) yang mana usia responden tersebut masuk pada usia reproduktif. Usia ideal seorang wanita hamil adalah pada rentang umur 20-35 tahun dimana umur tersebut termasuk reproduksi sehat, dimana pada rentang usia tersebut jarang terjadi komplikasi kehamilan dan secara biologis telah dipersiapkan dengan baik dan matang untuk bereproduksi. Dalam penelitian ini ibu hamil terbanyak adalah multigravida atau telah memiliki lebih dari satu anak sebanyak 23 orang (77\%). Ibu hamil dengan paritas yang tinggi cenderung mempunyai pengalaman dalam kehamilan dan persalinan sehingga merasa wajib memberikan ASI bagi bayinya.
Pendidikan ibu hamil terbanyak adalah berpendidikan SMA sebanyak 17 orang (57\%). Seseorang yang memiliki tingkat pendidikan yang tinggi maka untuk pengetahuan secara siknifikan akan memiliki pengetahuan yang baik pula. Menurut teori menyatakan bahwa orang yang memiliki tingkat pendidikan tinggi akan merespon yang rasional terhadap informasi yang datang dan akan berfikir sejauh mana keuntungan yang akan mereka dapatkan. Seseorang yang memiliki pendidikan tinggi akan lebih mudah menerima hal-hal baru sehingga informasi akan lebih mudah untuk diterima seperti penyuluhan khususnya penyuluhan tentang ASI eksklusif (Mariza, 2015).

Ibu hamil pekerjaan terbanyak adalah Ibu Rumah Tangga (IRT) sebanyak 17 orang (57\%). Dengan pekerjaan ibu sebagai IRT maka akan memiliki waktu lebih banyak dengan bayi dalam memberikan ASI Eksklusif dibandingkan dengan ibu yang bekerja.

\section{Pengetahuan ibu tentang ASI Eksklusif}

Pengetahuan pada post test atau setelah dilakukan penyuluhan tentang ASI 
Eksklusif dengan audio visual terdapat peningkatan kriteria pengetahuan ibu menjadi kriteria baik sebanyak 20 orang (20\%). Pengetahuan merupakan salah satu komponen yang dapat mewujudkan dan mendukung terjadinya suatu perilaku (Notoadmojo 2012). ASI eksklusif adalah pemberian ASI selama 6 bulan tanpa tambahan cairan apapun seperti susu formula, jeruk, madu, air teh, air putih, serta tanpa tambahan makanan padat seperti pisang, bubur susu, biskuit, bubur nasi, nasi tim, kecuali vitamin, mineral dan obatobatan (Roesli, 2012). Dengan adanya pengetahuan yang baik maka akan muncul keinginan berperilaku sesuai pengetahuannya untuk memberikan ASI Eksklusif kepada bayinya.

\section{Motivasi ibu untuk menyusui Eksklusif}

Motivasi reponden dalam menyusui secara eksklusif terdapat peningkatan motivasi setelah dilakukan pendidikan kesehatan. Motivasi akan terjadi apabila ada dorongan pada diri seseorang untuk melakukan sesuatu yang sesuai dengan dorongan dalam dirinya dan adanya dorongan dari luar atau dari lingkungan ( Notoadmojo, 2014).

Salah satu cara untuk memotivasi ibu dari luar dalam pemberian pendidikan kesehatan tentang ASI Ekskluif ini menggunakan pemicu untuk membuat seseorang termotivasi yaitu dengan menggunakan video dalam mendorong motivasi ibu untuk menyusui secara Eksklusif kepada bayinya. Motivasi yang berasal dari luar memiliki kekuatan untuk mengubah kemauan seseorang. Seseorang bisa berubah pikiran dari yang tidak mau menjadi mau berbuat sesuatu karena motivasi ini (Suhardi, 2013).

\section{Pengaruh pendidikan Kesehatan terhadap pengetahuan dan motivasi}

ASI eksklusif adalah memberikan air susu ibu saja sampai usia 6 bulan tanpa ada tambahan makanan lain kecuali obat vitamin mineral (WHO, 2010). Hasil penelitian menunjukkan pengetahuan ibu meningkat setelah diberikan pendidikan kesehatan dengan video ASI eksklusif baik sebanyak 26 orang $(86 \%)$ dan motivasi ibu setelah dilakukan pendidikan kesehatan berubah menjadi tinggi sebanyak 22 orang (73\%).

Berdasarkan uji statistik didapatkan hasil $p$-value sebesar 0,000 dengan taraf signifikansi $\mathrm{p}<0,05$ maka hipotesis diterima. Jadi hasil analisis menunjukkan ada pengaruh pendidikan kesehatan dengan audio visual terhadap pengetahuan dan motivasi ibu untuk menyusui secara eksklusif. Hasil penelitian ini bisa disimpulkan bahwa ada perbedaan pengetahuan dan motivasi sebelum dan sesudah diberikan pendidikan kesehatan dengan menggunakan audio visual. Setelah diberikan pendidikan kesehatan dengan audio visual pengetahuan dan motivasi bertambah baik dibandingkan sebelum menggunakan audio visual. Hasil penelitian ini sejalan dengan Notoatmodjo (2014), yang mengatakan bahwa pengetahuan atau kognitif merupakan domain yang sangat penting untuk terbentuknya tindakan seseorang, perilaku yang didasari oleh pengetahuan akan lebih langgeng dari pada yang tidak. Dengan semakin tingginya tingkat pengetahuan ibu maka tentunya ibu akan mempunyai perilaku yang baik pula dalam pemberian ASI kepada anaknya.

Hasil penelitian ini sejalan dengan penelitian Wicaksono (2016), dimana media audio visual pengaruh secara signifikan terhadap pengetahuan sikap dan perilaku ibu baduta di Puskesmas johar Baru dengan nilai signifikansi $p: 0,05$.

\section{SIMPULAN DAN SARAN}

\section{Simpulan}

Pengetahuan ibu tentang ASI Eksklusif setelah dilakukan penyuluhan tentang ASI Eksklusif dengan audio visual terdapat peningkatan kriteria pengetahuan ibu menjadi kriteria baik sebanyak 26 orang (86\%). Motivasi ibu untuk menyusui secara Eksklusif setelah pendidikan kesehatan dengan audio visual masuk kriteria tinggi sebanyak 22 orang (73\%). Pengaruh pendidikan kesehatan dengan audio visual 
Sekolah Tinggi Ilmu Kesehatan Bakti Utama Pati

tentang ASI Eksklusif berpengaruh dalam meningkatkan pengetahuan dan motivasi ibu untuk menyusui secara Eksklusif dengan nilai $p$ value sebesar 0,000 dengan signifikansi $\mathrm{p}<$ 0,05 .

\section{Saran}

Bagi tenaga kesehatan dalam memberikan pendidikan kesehatan dapat menggunakan audio visual agar lebih menarik dan mudah diterima.

\section{DAFTAR PUSTAKA}

Depkes RI. 2010. Capaian Pembangunan Kesehatan Tahun 2011. Jakarta.

Dinas Kesehatan Kota Surakarta. 2015. Profil Kesehatan Surakarta Tahun 2014.

\section{Surakarta: Dinas Kesehatan Kota} Surakarta.

Ikatan Dokter Anak Indonesia. 2011. Kumpulan Tips Pediatrik. Jakarta. Badan Penerbit Ikatan Dokter Indonesia

Kementrian Kesehatan Indonesia. 2013. Profil Kesehatan Indonesia Tahun 2012. Jakarta: Kementrian Kesehatan Indonesia.

Khasanah. N. 2011. ASI atau susu Formula ya? Panduan Lengkap Seputar ASI dan Susu Formula. Yogyakarta. Flashbook

Mariza, 2015. Hubungan Pendidikan dan pekerjaan ibu dengan pemberiamn ASI Ekskluif. Jurnal Dunia KesMas Volume 4. Oktober 2015.

Notoatmodjo, S. 2010. Metodologi Penelitian Kesehatan. Jakarta: Rineka Cipta. 